\title{
GD Usernames and Euphemism: A Morphosemantic Analysis
}

\author{
Hamada S. A. Hassanein ${ }^{182}$ \\ ${ }^{1}$ College of Science \& Humanities, Prince Sattam bin Abdulaziz University, Alkharj, Saudi Arabia \\ ${ }^{2}$ College of Education, Mansoura University, Mansoura, Egypt \\ Correspondence: Hamada S. A. Hassanein, College of Science \& Humanities, Prince Sattam bin Abdulaziz \\ University, Alkharj 11942, Saudi Arabia. E-mails: h.hassanein@psau.edu.sa or kheshin@mans.edu.eg
}

Received: May 15, 2019 Accepted: July 15, 2019 Online Published: August 26, 2019

doi:10.5539/ijel.v9n5p107 URL: https://doi.org/10.5539/ijel.v9n5p107

\begin{abstract}
Gamedesire (GD), a free online gaming website, is a rich resource for language research on Computer-Mediated Communication (CMC). GD raises a number of linguistic inquiries on written English. This paper analyzes the morphosemantic mechanisms of forming euphemistic GD usernames. A dataset of two hundred usernames has randomly been selected and tested against Warren's (1992) model. The study demonstrates that a plethora of GD usernames carry dysphemistic connotations that are denotatively euphemized with linguistic and paralinguistic mechanisms, including word formation, orthographic modification, borrowing and semantic innovation. Some of the dataset usernames could not be subsumed under the selected model, necessitating the addition of new devices and the development of a new rendition of the model. The study reveals that GD users employ several processes for creating their usernames, which are characterized by grammatical, lexical, phonological, graphological, and semantic deviations from language norms.
\end{abstract}

Keywords: euphemism, gamedesire, usernames, sex, denotation, connotation, morphosemantics

\section{Introduction}

As Graham (1999) puts it, the Internet began life as a US military communications system to provide a whole secure means by which secret information could be circulated. van Dijk (2006) defines the Internet as "global connection of hundreds of thousands of public and private computer networks by means of public exchanges, that is, nodes, gateways, and computer centres using the TCP/IP protocol." van Dijk (2006) strictly indicates that the Internet and the World Wide Web are not the same. The former is a system of electronic intercommunication; the latter a way of processing and presenting digital information. The liberty of the Internet, he continues, is tailor-made to encourage a descent into 'licence' and its logical terminus is moral fragmentation. Such fragmentation is anarchic, since it is a means for the release and confluence of untutored desires of any and every kind. van Dijk (2006) identifies a striking feature of the Internet, i.e., internationalism, which connects people across several different nations in what Herring (1996) terms computer mediated communication (CMC), communication taking place between human beings via computers. Computer-mediated communication is said to comprise three main modes or mediums: e-mails, chat rooms, and instant messages. Todd and Walker (2000) hold that chat sites allow people all over the globe to 'talk' in real-time via their computer keyboards. Quirk and Stein (1990) point out that the second half of the twentieth century saw the explosive growth of the need for an international language. As Quirk (1982) explains it, English has rated a greater world spread than any other language over a century; it has been functioning as the lingua franca in the so-called 'global village'. Herring (1996) finds it typed like writing, but exchanges are rapid and informal, and hence more like spoken conversation. It is called spoken writing or written speech, a variety of English warranting investigation.

\subsection{Problem Statement}

The basic theory of euphemism developed by Warren (1992) and applied and modified by Ham $(2001,2005)$ has some caveats. Some constituents of the original and modified models are problematic as follows:

- There is no distinction between derivation and loanwords. Derivation and loanwords are understood therein as borrowing foreign words from other languages into English. The term 'derivation' is found pleonastic and ambiguous; 'pleonastic' because the term 'loanwords' can be used instead to convey the same meaning and 'ambiguous' because it can be assigned two different meanings, a) word borrowing and b) word formation (see Matthews, 1991; Bauer, 2003; Booij, 2005; Kennedy \& Zamuner, 2006). 
- The term blends has been unduly explained and exemplified. The scholarly explication and implementation of this term is still undeveloped. Ham (2001) concedes that euphemistic examples of blends are fairly rare and remain to be found and unjustifiably suggests that the category of blend be removed from the model until evidence of its validity is produced or be listed under phonemic replacement. Both the concession and the suggestion are debatable.

- Considering the term reversal synonymous with the term irony is controversial. The former is literary (see Prince, 2003; Baldick, 2004; Mikics, 2007); the latter linguistic (see Ford, 1968; Leech, 1969, 1983; Hatim, 1997).

- $\quad$ No difference is made clear between acronyms and abbreviations therein. An acronym is a pronounceable word (read like a normal word) formed from the initial letters of two or more words as in laser (see Haspelmath \& Sims, 2010; Bauer, 2003), whereas an abbreviation is a combination of two or more initial letters read alphabetically and standing for a full form as in $D J$ or NHS. Abbreviation is referred to as alphabetism (see Haspelmath \& Sims, 2010) and is said to fall into initialism, acronym and clipping (see McArthur, 2008). Acronym is subsumed by Warren (1992) under word-formation; abbreviation under phonemic modification.

These problematic issues necessitate removing the existing limitations and reconsidering the previous models. It is also assumed that a number of the collected Gamedesire usernames may not be subsumed under any of the categories developed by Warren and Ham. Therefore, a new rendition of the model is needed to include these usernames. To recap then: Warren (1992) and Ham $(2001,2005)$ introduced their insights into the linguistics of euphemism in a literary world. This paper reexamines these insights with application to logins in a virtual GD world.

\subsection{Research Objectives}

The main objectives of this article are

- to conduct a morphosemantic analysis of the mechanisms language users employ to create their usernames (logins) on the URL http://www.gamedesire.com; and

- to identify their intended dysphemistic referents. This analysis was conducted by investigating a dataset of 200 usernames collected randomly from the GD website.

\subsection{Research Questions}

To achieve these objectives, the study raises the following questions:

- Which linguistic mechanisms do users employ in forming their euphemistic usernames on the Gamedesire website?

- Which mechanisms register higher frequency than others?

- Do the usernames maintain their lexical meanings or do they take on new sexual connotations?

\section{Gamedesire (GD): A Global Village}

Gamedesire is a meeting website for thousands of people where they log in everyday to play and converse with one another. Before establishing a Gamedesire account, users must abide by the rules of the Gamedesire etiquette, the most important of which are nicknaming and chatting. The former is the point of departure there and here, concerning which a nickname should not be racially, religiously, historically or sexually offensive to others and should not also be vulgar. Forbidden also are the shortcuts of swears and the misleading usernames (see http://www.gamedesire.com/dd-10,n-3.html) (Note 1). If users do not follow the rules, their access to the website will be banned. Necessity being the mother of invention, they tend to employ evasive ways to break the rules and sign up with whatever usernames they fancy. Their most helpful mechanism in doing so is euphemism. Alternatives, though denotatively euphemistic, carry dysphemistic connotations. In this way, the censorship is rendered futile and users protect their usernames from banning and maintain access to the GD website. Being relatively impermanent informal names, usernames give the users a linguistic licence in breaking the rules (de Clerk \& Bosch, 1997). Usernames also characterize their bearers in some respect, such as sex, location and orientation.

The discipline under which the study of usernames falls is known as onomastics. Lapierre (2000) believes that onomastic studies have emerged as a true discipline of convergence, drawing on and bringing together the methodologies of several disciplines, mostly in social sciences and humanities. A salient focus of onomastics as an autonomous discipline is (user)names. Usernames are universal (Liao, 2006). de Klerk and Bosch (1997) 
point out that usernames as optional and transient terms of address and reference can provide insights into social relationships, culture and language (cited in Gladkova, 2002). The choice between usernames is context-based and the motivation for it is either euphemistic (substituting an inoffensive word for an offensive one) or evasive (replacing an impermissible username with a permissible one). According to Allan and Burridge (2006), styles of naming are affected by the speaker's attitude and by the perceived role and status, within the context of talk exchange, of the speaker and the person addressed or named. Names can be descriptive, picking up on a salient characteristic perceived in, wanted for, or (sometimes ironically) imputed to the referent. Just so are usernames.

\section{Theoretical Preliminaries}

\subsection{Euphemism}

A language without euphemisms would be a defective instrument of communication (Burchfield, 1985).

He who looks for offence will find it everywhere. He who concerns himself with euphemism, that mode of avoiding offence, will find it everywhere too (Enright, 1985).

Burchfield (1985) mentions that the word euphemism was first recorded in English in Thomas Blount's Glossographia (1665). The universal prevalence of euphemism as a principle of language is due to a belief in the mystic power of words to work their own fulfilment, as one of the laws of destiny (Friend, 1881). Diebold (1961) regards euphemism as a concept which does not lend itself to rigorous definition. However, the following lines provide some definitions of euphemism. Euphemism is defined by Diebold (1961) as 'an expression (or a set of expressions) demanding palliation'; by Webster's Third New International Dictionary (1961) as 'a polite, tactful, or less explicit term used to avoid the direct naming of an unpleasant, painful, or frightening reality' and by the Concise Oxford Dictionary (1982) as 'substitution of mild or vague or roundabout expression for harsh or blunt or direct one' (cited in Burchfield, 1985); by Jones (1980) as 'a figure of speech by which a harsh or unpleasant fact is given a milder or more gentle expression or is expressed in a more roundabout way' (quoted in McKenzie, 1992); and by Fan (2006) as 'roundabout expressions, substituting indirect, vague, pleasant and mild words for more explicit and offensive ones, with the purpose of avoiding taboos, showing elegance or avoiding hurting other people's feelings.'

Authors in the field hold different views on whether the use of euphemism is positive or negative as summed up below:

- The use of euphemism is common in everyday life, as in 'sleep' for 'dying'; 'covers one's feet' for 'urinating'; 'to know' for 'coition'; and 'the way of women' for 'menstruation'. These euphemisms are straightforward and representative of little difficulty either to the ancients or to contemporary readers (Ford, 1968).

- Euphemism is the British linguistic vice (Lancastrians are the exception; just as hyperbole is the American; coarse slang the Australian; blarney the Irish; pedantry the Indian; and a whining pronunciation the South African (Howard, 1984).

- Words themselves are euphemisms for what they represent and can hurt you in diverse ways - by telling the truth, by telling less than the truth, or by telling more than the truth. The shift of 'genuine' euphemism into the public sphere, political, military, commercial, and social, can do much more harm than it ever did in the largely private realms of sex, bowel movements, menstruation, money, sickness, and natural death (Enright, 1985).

- Invention being the mother of necessity, the need for euphemism arose and nowhere could this need have been greater, or more evident, than in the realm of sex. Removal of euphemism from the realm of discourse about sex leaves one with two undesired possibilities: a) to speak about it clinically and b) to speak not so much plainly as profanely (Epstein, 1985).

- Euphemistic language has traditionally been scorned as a fearful evasion of the truth, of open, frank statements of 'reality'. There are two problems with euphemism: a) to categorize euphemism as a deviation from a norm is to place it in a hierarchy that is implicitly moral. Euphemism is furtive, fearful, indirect, circumambient, imprecise, and non-concise. The other problem is that it is not always easy to identify the 'normal' word from which the euphemism is supposed to be deviating (Robinson, 1991) (Note 2).

- Whether euphemism functions better as expletives often depends on a speaker's illocutionary situation and is probably a matter of taste (Adams, 1999).

- Euphemism intimates as well as blurs erotic meanings (Matheson, 1999).

- The need for euphemism is both social and emotional, as it allows discussion of 'touchy' or taboo subjects 
such as sex without upsetting other people. The function of euphemism is to protect the sender/receiver from possible effrontery and offence (Ham, 2005).

- Some experiences are too intimate and vulnerable to be discussed without linguistic safeguards; one of these is death. People tend to use euphemism as a tool of mentioning the unmentionables (Crespo-Fernández, 2006).

Euphemism prevails the arena of sex. In the vast history of humanity, sex was publicly unspeakable. Nowadays it has become one of the much-tackled topics everywhere on radio, television, dish satellite, the Internet and at schools and universities. The Internet changed social perceptions of sex, by making it more accessible, more exchangeable and more visible. The emergence of computer-mediated communication modes, chatrooms in particular, have drastically changed attitudes towards sex. "The subject of sex, being a major concern in human life and one that is likely to elicit embarrassment, is a potent source of euphemism for people of most ages and walks of life" (Ham, 2001, p. 11). Epstein (1985) contends that sex may be spoken of tenderly or toughly, lyrically or lasciviously, beautifully or brutally, and in all these various ways by the same person on the same day. Santaemilia (2005) admits that the language employed to denote sex is worthy of observation and research. Crespo-Fernández (2015) approaches sex from a cognitive linguistic perspective by analyzing two antithetical terms of verbal mitigation and offence: euphemism and dysphemism.

\subsection{Politeness}

The notion of politeness has been into much interest since its development by Brown and Levinson (1978; 1987). Holmes (1995) defines it as 'an actively expressing positive concern for others, as well as non-imposing distancing behaviour' - a definition describing politeness as showing concern for 'facework'. He suggests that politeness can be expressed verbally and non-verbally. Meier (2005) views politeness as appropriateness, which leads to the rejection of equating politeness with specific speech acts, lexical items, or syntactic constructions. Escandell-vidal (1996) describes politeness as indirectness and indirectness as implicitness. The relation between politeness and indirectness is considered from two different points of view: a) the reason for being indirect is to be polite and b) the best way to be polite is to be indirect. Leech (1983) characterizes politeness as relative and absolute. Relative politeness refers to the politeness of an act relative to a particular context, whereas absolute politeness refers to the politeness associated with acts independent of context (cited in Culpeper, 1996). Precisely, politeness is a mere idiolect, i.e., people have their own ways of appearing polite. Politeness can be considered as relative as beauty and what counts as polite varies between individuals and communities. The point is what is regarded as polite yesterday might not be polite today and what is considered polite today might not be polite tomorrow. As Allan and Burridge (2006) put it, politeness is wedded to context, place and time.

\subsection{Face}

From the preceding standpoints, it can be deduced that the concept of face is intrinsic to politeness theory. Hatim (1997) views politeness as centering on the notion of face, i.e., the attempt to establish, maintain, and save face in interaction with others. Goffman (1967) conceptualizes face as a construct with universal applicability and defines it as 'the positive social value a person effectively claims for himself by the line others assume he has taken during a particular contact' (cited in Kadt, 1998). Allan and Burridge (2006) perceive social interaction as generally oriented towards maintaining (saving) face, and just as we look after our own face (self-respect), we are expected to be considerate of, and look after, the face-wants of others. They distinguish between 'positive face' (a person's desire to be liked and valued) and 'negative face' (a person's desire to act freely and without hindrance). Holmes (1995) draws the same distinction between a negative face (the need not to be imposed upon) and a positive face (the need to be liked and admired). Then face is a self-image that can be saved or threatened in different ways. Briefly, one motivation behind the use of euphemism is to sound polite and save one's own face as well as the faces of others.

\subsection{Taboo}

Hayakawa (1965) states that there seem to be certain 'unmentionables' in everyday language. These are verbal taboos which Allan and Burridge (2006) regard as proscriptions of behaviour that affect everyday life. Calvo (2005) extends the term taboo to all those words or sets of words referring to objects, concepts or actions that a given society considers to be individually or collectively subject to proscription. Allan and Burridge (2006) state that (im)politeness is examined in its interaction with orthophemism (straight talk), euphemism (sweet talk), and dysphemism (offensive talk). Dysphemism is technically defined as 'a word or phrase with connotations that are offensive either about the denotatum or people addressed or overhearing the utterance', whereas orthophemism and euphemism are defined as 'words or phrases used as an alternative to a dispreferred expression which can be dubbed tabooed expression.' Their so-called X-phemisms (the union of set of orthophemisms, euphemisms, and 
dysphemisms) are contrasted in Table 1.

Table 1. Contrasting X-phemisms

\begin{tabular}{lll}
\hline orthophemism & euphemism & dysphemism \\
\hline faeces & poo & shit \\
toilet & loo & shithouse \\
menstruate & have a period & bleed \\
vagina & bits & cunt \\
\hline
\end{tabular}

Table 1 shows different synonyms indicative of one single designatum that can be referred to orthophemistically, euphemistically or dysphemistically.

The X-phemisms are also related in Figure 1.

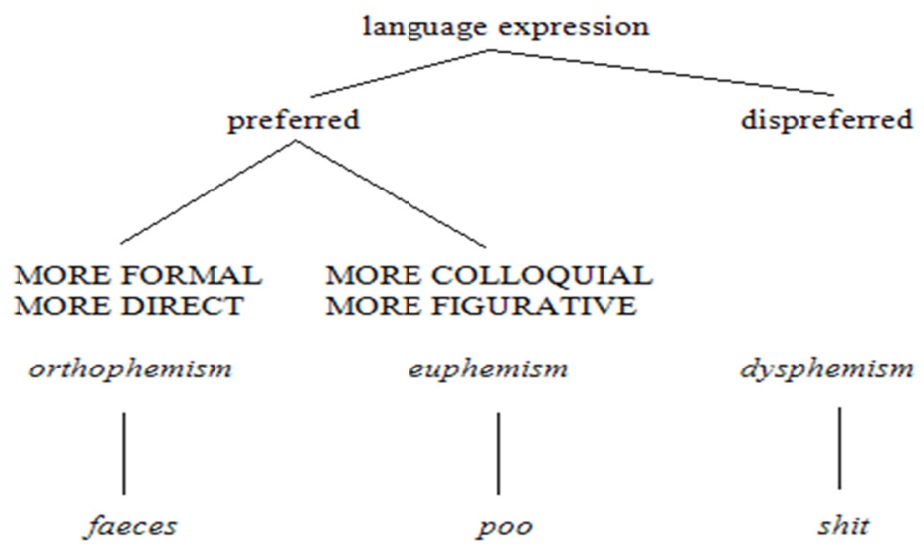

Figure 1. Distinguishing X-phemisms

Figure 1 demonstrates that linguistic expressions are either preferred or dispreferred depending on the mode of language whether formal or colloquial and direct or figurative. Formal and direct expressions are orthophemistic; colloquial and figurative ones are euphemistic. The dispreferred expressions are dysphemistic taboos. However, Hayakawa (1965) ascribes a genuine social value to them. In a state of extreme anger, e.g., the uttering of forbidden words, such as 'shit' and 'fuck', provides for a relatively harmless verbal substitute for going berserk and smashing furniture. His view is very meaningful: anger expressed in words is safer than anger expressed in actions.

\section{Literature Review}

Fan (2006) states that literature on euphemism made considerable achievements under the scopes of rhetoric, lexicography, semantics, sociolinguistics, psycholinguistics, Fuzzy Theory and pragmatics. The literature can be divided into three categories: (a) works on theorizing euphemism (e.g., Howard, 1984; Enright, 1985; Allan \& Burridge, 1991; Warren, 1992), (b) works on applying the theory to data from various cultures and languages (e.g., Friend, 1881; Cunningham, 1956; Diebold, 1961; Ford, 1968; Hedges, 1976; Marcus, 1980; Robinson, 1991; Adams, 1999; Hines, 1999; Matheson, 1999; Ham, 2001, 2005; Fan, 2006; Crespo-Fernández, 2006, 2015; Cooper, 2008; La Cour \& Kromann, 2011; Rabab'ah \& Al-Qarni, 2012), and (c) works only referring to the term (e.g., al-Khamash, 1991; Spira, 2005). Euphemism relating to the formation of Gamedesire usernames has not been investigated yet. Even the original work by Warren (1992) and almost all euphemism studies which followed focused on different genres than the one under scrutiny. This paper conducts a euphemastic analysis of an under-researched topic - nicknaming. The paper is hoped to be second to none, since no scholarly attention has been paid to the claim that users' sexual orientation has greatly impacted their linguistic behaviour of creating their usernames on the Gamedesire website.

\section{Method}

The present study seeks to retrieve and replicate an existing model of euphemism developed by Warren (1992) and modified by Ham (2001, 2005). Warren (1992) bases the model on the premise that "novel contextual 
meanings", new meanings for words in a particular context, are constantly created in language. This creation is rule-governed and the acceptability of new meanings depends on, for example, the strength of ties between the novel term and its referent, whether the novel term is considered to be of lasting value, i.e., the referent has no other name, or if the novel term is a "desirable alternative" (cited in Ham, 2005). Warren categorizes euphemism formation into four main devices and sub-devices. Ham (2001) explicates and exemplifies these devices in the modified version. It would be futile to repeat what she has done, since the purpose is to build on the previous scholarly attempts. The model is shown in Figure 2.

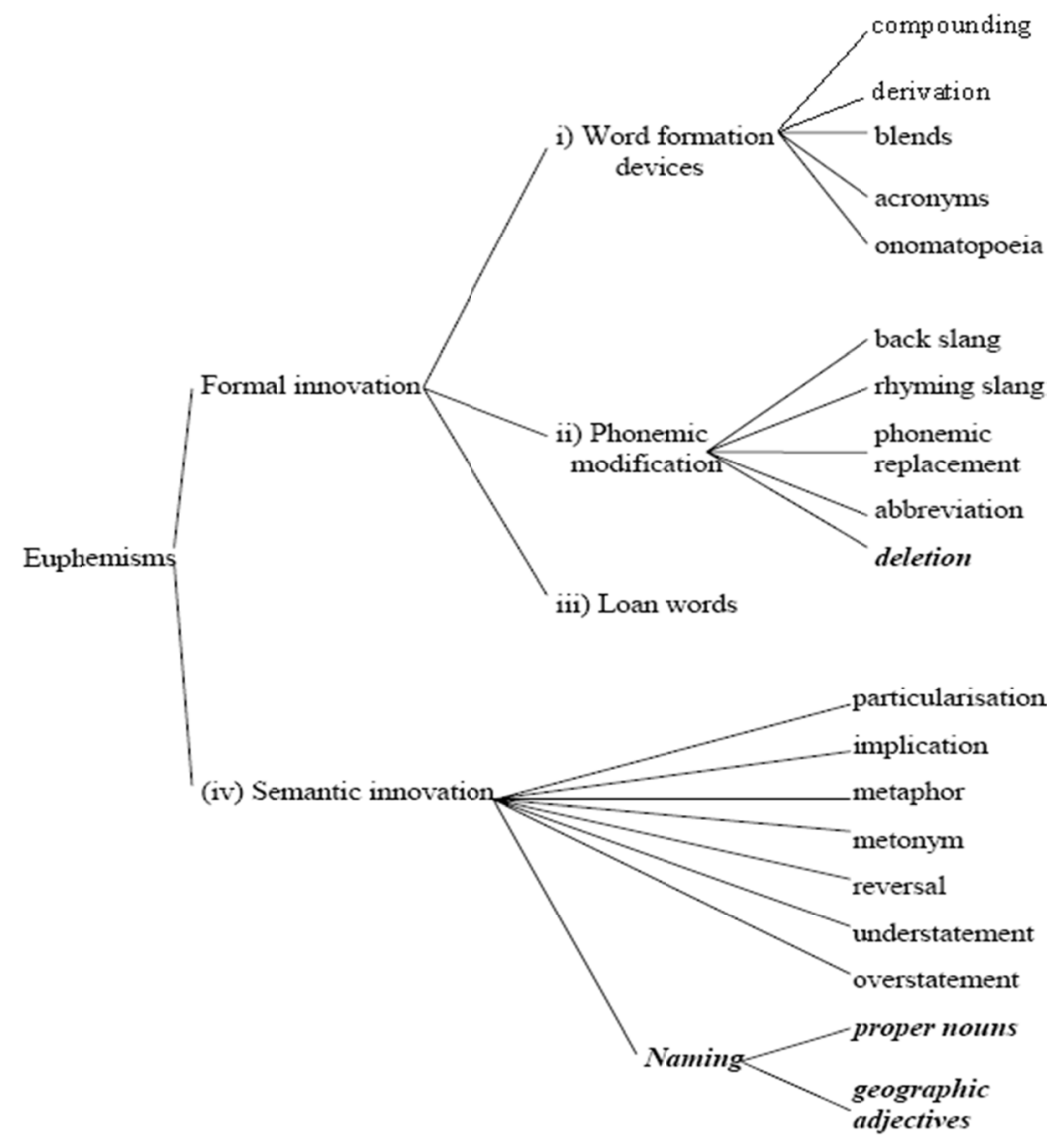

Figure 2. Warren's (1992) model as modified in Ham (2001, 2005)

As shown on Figure 2, Warren's model (1992) identifies four main ways in which euphemisms are formed: (i) word-formation processes including compounding (combining two words to form a new one), derivation (adding affixes to an existing word to form a new one), blending (joining parts of existing words to form a new one), acronymy (forming a new pronounceable word from the initials of existing words), onomatopoeia (making a new word from the sound associated with it); (ii) phonemic modification altering the form of offensive words into inoffensive ones according to particular rules, such as back-slang (using an offensive word in a reversed spelling order), rhyming slang (replacing an offensive slang with another inoffensive one that rhymes with it), phonemic replacement (substituting a phoneme in the offensive word with another phoneme), abbreviation (giving a shortened form of the offensive word), deletion (Ham's term, ellipting parts of words or eliding sounds thereof); (iii) loanwords (borrowing foreign words from other languages in place of the offensive ones); (iv) semantic innovation creating a novel sense of an established word or word combination, as in particularization (narrowing the conventional meaning of a taboo to a particular contextual one), implication (accompanying the conventional meaning with a contextually implied one), metaphor (founding an affinity between some property of the conventional referent and of the contextual referent), metonymy (finding co-occurrence relation between the conventional and contextual referents), reversal (reversing the conventional meaning to fit the contextual), understatement (downgrading the conventional meaning of a word to fit a contextual referent), overstatement (upgrading the conventional meaning of a word to fit a contextual referent) and naming (Ham's term, employing a word that designates a specific person or place). 


\section{Dataset}

Gamedesire (GD) provides a sign-up page so that interested visitors can register by creating a login through the URL http://www.gamedesire.com/dd-1,n-2.html. As a result of the registration, they become entitled to send and receive messages, chat in multinational lobbies, and play at public or private tables. A randomly selected, but representative, sample of 200 euphemized usernames was collected and then tested against Warren's (1992) model as modified by Ham $(2001 ; 2005)$. By 'representative', it is meant that an example can be typical of a great many of other similar examples, since the purpose is not to list but to exemplify. The usernames were collected from their respective profiles. Clickable URLs of the usernames so selected can be navigated by adding a username (e.g., handjob) to the main URL http://www.gamedesire.com and then pressing the 'Ctrl' button to be directly taken to the player's profile (e.g., http://www.gamedesire.com/player/handjob) if connected to the Internet. During the phase of data collection, some limitations occurred: a) regular members could sign in as guests and, therefore, it was not possible for other members to identify them; $b$ ) it was sometimes difficult to distinguish between the meaning intended by the addresser (what ' $I$ ' meant) and that received by the addressee (what 'you' got); c) the majority of the profiles did not provide any personal details and could be created and deleted on the same day; d) some usernames might be ambiguous because they could be interpreted in different ways, at least one of which is the case; e) a request was made to the website administrator to provide a list of usernames, but it was denied. The sample of usernames collected for analysis is provided in Table 2. These usernames are investigated in the next section and classified into a fitting category as covered by Warren (1992) and Ham $(2001,2005)$. Usernames not fitting into any of the categories necessitated creating new ones. All categories are combined in a new version of the model (See Appendix 1).

Table 2. A sample of 200 usernames collected from http://www.gamedesire.com

\begin{tabular}{|c|c|c|c|c|}
\hline handjob & tos & $\mathrm{meq}$ & balls & monthy \\
\hline funbun & ufo & QT & threedoors & $69 \mathrm{er}$ \\
\hline hotspot & WaiLing & TL & globes & $(! !)$ \\
\hline moneymaker & AW & uns & Screwed & $(!+\ldots)$ \\
\hline spermbank & moan & XTC & RIDER & (y) \\
\hline fuckstick & oooooo & $3 \mathrm{cs}$ & he/she & (.)(.) \\
\hline chachas & woohoo & eff & himher & $(\mathrm{o})(\mathrm{o})$ \\
\hline Meatballs & Groan & sayha & he & $\{\}.\{\}$. \\
\hline nOsEbLeEd & mng & doody & She & ahole \\
\hline Handshake & bonk & NotGood & cumcum & peepee \\
\hline HELLOKITTY & vibrate & paramour & rear & googoo \\
\hline BackDoor & Tremble & untouchable & DoIt & weewee \\
\hline brownhole & have & clean & sitonit & woowoo \\
\hline fornix & LARO & getitup & TakeIt & DillyWilly \\
\hline Geschlecht & xes & lover & mything & awawaw \\
\hline pene & epar & mistress & ugly & ohohoh \\
\hline Dirne & sinep & enjoyable & SoCold & awawawaw \\
\hline Puta & toh & Cute & freezy & ohohohoh \\
\hline lesbica & tew & pretty & chilly & 9966 \\
\hline Gai & DEKCUF & wetnwild & icicle & 39 \\
\hline schmock & RENOB & delicious & badlooking & 63 \\
\hline trois & tilc & Luscious & indifferent & clit \\
\hline fellatiO & Lana & SaTisFacTioN & Notbad & cgirl \\
\hline Breasticles & DEKAN & sleeper & Unwilling & $\mathrm{BigV}$ \\
\hline sexpert & 624 & touchme & unwanted & nympho \\
\hline SEXERCISE & 46 & pleasurable & eatenup & butt \\
\hline Pedophile & Bristols & Passionate & edible & $\operatorname{trani}$ \\
\hline crunk & Ripple & intimate & steamy & porno \\
\hline DASS & ronson & GetLaid & Dirty & sexme \\
\hline moobs & berk & willing & TWISTY & beerme \\
\hline Sexilicious & brass & BackDoor & OILED & nake \\
\hline sexited & kitt & frontdoor & TooHungry & Lech \\
\hline Girlicious & grunt & 6ybeast & impassioned & liaise \\
\hline Fugly & grundies & Preyer & Burning & cAsAnOvA \\
\hline BAMF & fritter & Gates & lewd & donjuan \\
\hline bab & letsdo & make & flaming & juliuscaesar \\
\hline Emp & zex & a.h. & FlamingLips & redsea \\
\hline fub & 6ykitten & swak & Delirious & Buttocks \\
\hline Gypo & azz & CaptainHook & kinky & loose \\
\hline wafda & sixo & cex & jap & thrill \\
\hline
\end{tabular}




\section{Analysis}

\subsection{Euphemisms Fitting into Warren's (1992) and Ham's $(2001,2005)$ Categories}

\subsubsection{Word-Formation Devices}

\subsubsection{Compounding}

$\begin{array}{llll}\begin{array}{l}\text { Username } \\ \text { handjob }\end{array} & \text { Connotation } & \text { Username } & \text { Connotation } \\ \text { Handshake } & \text { male masturbation } & \text { fuckstick } & \text { penis } \\ \text { HELLOKITTY } & \text { male masturbation } & \text { chachas } & \text { breasts } \\ \text { funbun } & \text { female masturbation } & \text { Meatballs } & \text { breasts } \\ \text { hotspot } & \text { vagina } & \text { nOsEbLeEd } & \text { menstruation } \\ \text { spermbank } & \text { vagina } & \text { BackDoor } & \text { asshole }\end{array}$

Grammatically, the compound euphemisms above constitute compound noun phrases made up of two words: a noun or an adjective functioning as a pre-modifier of another noun and combined together in a solid shape of one word. Phonologically, compounds occur in two forms: (a) word stress with the pattern " $/-x$ " (primary-tertiary) and compound stress with the reversed pattern " $x_{-} /$" (tertiary-primary). The compound euphemisms 'handshake', 'chachas', 'meatballs', and 'nosebleed' belong to the former type; the rest to the latter. Compounds of the former type transfer us from the lexical sphere to the sexual whereby 'handshake', 'chachas', 'meatballs', and 'nosebleed' connote 'masturbation', 'breasts', and 'menstruation', respectively. Compounds as such show the users as more highly productive in dressing lexical items with new connotative senses that are semantically opaque. These compounds are exocentric since the whole meaning of the compound cannot be figured out from the meanings of its parts.

\subsubsection{Derivation}

\begin{tabular}{|c|c|c|c|}
\hline Username & Connotation & Username & Connotation \\
\hline Bitcher & pimp & asser & anal fucker \\
\hline BUTTING & anal fucking & & \\
\hline
\end{tabular}

The word derivation is used here as a process of affixation (see Bauer, 2003; Matthews, 1991), not as borrowing in Warren's or Ham's sense. Gamedesire users exceed the normal resources of the English language, by adding a nominal bound-morphemic suffix, e.g., "-er" (doer) and "-ing" (doing), to certain existing lexical entries with familiar meanings to defamiliarize them for euphemistic purposes. Such derivatives challenge the norms of English derivational morphology by changing the form of the base. Items such as "bitch", "butt", and "ass" are lexically entered as nouns but are treated here by means of conversion as verbs "to bitch", "to butt", and "to ass". These are typical examples of lexical deviation from the linguistic norm.

\subsubsection{Blending}

$\begin{array}{lll}\text { Username } & \text { Connotation } & \text { Username } \\ \text { Breasticles } & \text { breasts + testicles } & \text { Fugly } \\ \text { sexpert } & \text { sex + expert } & \text { moobs } \\ \text { SEXERCISE } & \text { sex + exercise } & \text { Sexilicious } \\ \text { Pedophile } & \text { child + fucker } & \text { Girlicious } \\ \text { crunk } & \text { cruel + drunk } & \text { sexited } \\ \text { DASS } & \text { dumb + ass } & \end{array}$

These are euphemistic blends formed by clipping part of one word or two and then combining the clipped parts together in single words referred to as portmanteau words (see Haspelmath, 2002; Bauer, 2003; Crystal, 2003, 2008). Blending serves here as a very rich source of new words pragmatized online but not yet lexicalized. Out of these blends, only "pedophile" has a standard lexical entry; "crunk" (cruel + drunk) bears an orthographic affinity to "crunk" (a type of rap music). The rest are nonce words serving gap-filling purposes on particular occasions and functioning as midway euphemisms between two distinct words, one or both of which are dysphemistic.

\subsubsection{Acronymy}

$\begin{array}{llll}\begin{array}{l}\text { Username } \\ \text { BAMF }\end{array} & \text { Connotation } & \text { Username } & \text { Connotation } \\ \text { ufo } & \text { bad ass mother fucker } & \text { wafda } & \text { what a fucking dumb ass } \\ \text { unbelievable fantastic orgasm } & \text { Gypo } & \text { get your penis out } \\ \text { tos } & \text { trick off the street } & \text { fub } & \text { fuck you bitch } \\ \text { swak } & \text { sealed with a kiss } & \text { Emp } & \text { eat my pussy } \\ \text { jap } & \text { Jewish American princess } & \text { bab } & \text { big ass boobs }\end{array}$

Gamedesire users abbreviate a full-form multiword dysphemistic expression in a pronounceable euphemistic 
word formed successively from the initial letters of the constituent words. Full-form dysphemisms are ineffable and it is ineffability that forces the users not to use expansions but to resort to initialisms instead because of spatial and technical constraints. Space allowed for a sign-up is limited by the login screen and an offensive username causes face-threatening acts in chatrooms. Therefore, the need for acronymy arises. As a euphemism-forming mechanism, acronymy becomes widespread through frequent use online.

7.1.1.5 Abbreviation

$\begin{array}{llll}\begin{array}{l}\text { Username } \\ \text { a.h. }\end{array} & \text { Connotation } & \text { Username } & \text { Connotation } \\ \text { mcq } & \text { asshole } & \text { tp } & \text { triple-penetra (penetration) } \\ \text { QT } & \text { McQuickie (quick sex) } & \text { uns } & \text { Undies (underwear) } \\ \text { TL } & \text { cutie } & 3 \mathrm{cs} & \text { threesies (threesome sex) } \\ \text { porno } & \text { tuchus leker (ass licker) } & \text { eff } & \text { effing (fucking) } \\ \text { trani } & \text { sex materials } & \text { nympho } & \text { excessive sexual desire } \\ & \text { transsexual } & \text { ahole } & \text { asshole }\end{array}$

Scholars (see Crystal, 2003, 2008; McArthur, 2008) consider abbreviation an umbrella term including acronymy, initialism (alphabetism (Haspelmath, 2002)), and clipping (truncation (Plag, 2003)). Crystal (2008) establishes that abbreviation is a process of distinguishing many ways in which words can be shortened: initialisms or alphabetisms, acronyms, clippings, and blends. Gamedesire users are prolific coiners of novel abbreviations, shortening words whose expansion is offensive into inoffensive abbreviated forms. Such forms are gradually popularized with the advance of online technology and become a fast-disseminating trend on the website. The website etiquette creates a great demand for shorter, more compatible forms which keep avid seekers of sex on the safe side.

\subsubsection{Onomatopoeia}

$\begin{array}{llll}\text { Username } & \text { Connotation } & \text { Username } & \text { Connotation } \\ \text { WaiLing } & & \text { Groan } & \\ \text { moan } & & \text { bonk } & \\ \text { oooooo } & \text { sexual orgasm } & \text { vibrate } & \text { sexual orgasm } \\ \text { woohoo } & & \text { Tremble } & \\ \text { AW } & & & \end{array}$

At the height of sexual arousal during the intercourse, orgasm or excitement is paraverbally or nonverbally expressed. Sex partners transmit their intense sexual pleasure through paraverbal means as in the tone, pitch or pace of wailing, moaning, groaning and bonking or nonverbal means through physical reactions as a vibration, a tremble, or a thrill. Gamedesire users log in with onomatopoeically euphemistic usernames evocative of the sounds produced during sexual intercourse.

\subsubsection{Phonemic Modification}

\subsubsection{Back Slang}

$\begin{array}{ll}\text { Username } & \text { Connotation } \\ \text { LARO } & \text { oral } \\ \text { xes } & \text { sex } \\ \text { epar } & \text { rape } \\ \text { sinep } & \text { penis } \\ \text { toh } & \text { hot } \\ \text { DEKCUF } & \text { fucked }\end{array}$

$\begin{array}{ll}\text { Username } & \text { Connotation } \\ \text { tew } & \text { wet } \\ \text { RENOB } & \text { boner } \\ \text { Tilc } & \text { clit } \\ \text { Lana } & \text { anal } \\ \text { DEKAN } & \text { naked }\end{array}$

Back slang is an unconventional variety of English in which vulgar usernames are euphemized by a full reversal of their spellings, i.e., written or spelled backwards. This is a common device employed by Gamedesire users to pass off their offensive usernames to the website and to incapacitate administrators' execution of a ban.

\subsubsection{Rhyming Slang (Note 3)}

$\begin{array}{lll}\text { Username } & \text { Connotation } & \text { Username } \\ 624 & \text { sex to whore } & \text { brass } \\ 46 & \text { for sex } & \text { kitt } \\ \text { Bristols } & \text { breasts (Bristol City, i.e., tity) } & \text { grunt } \\ \text { Ripple } & \text { nipple } & \text { grundies } \\ \text { ronson } & \text { anus (ronson lighter) } & \text { fritter } \\ \text { berk } & \text { cunt (Berkshire Hunt) } & \end{array}$

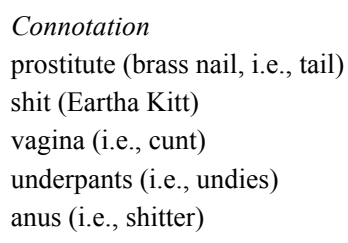

Rhyming slang usually involves a two-word phrase whose last word rhymes with the target word and the meaning of the whole phrase is unlikely to have any relation to the target word (Wherrett, 2009). Those rhyming 
slang usernames vary, however, from three- to two- to one-word phrases (nominal and prepositional) used so as not to be comprehended by the outsiders. Most of the usernames are minimal pairs whose members share all sounds but one (see Crystal, 2008), as in 'sex/six', 'whore/four', 'shit/Kitt', and 'nipple/ripple'. The rest hold fully or loosely consonantal or assonantal affinities. Both back slang and rhyming slang amount to what Halliday (1978) terms 'antilanguages'. They give rise to a new register of English, a major threat of overlexicalization to standard English.

\subsubsection{Phonemic replacement}

$\begin{array}{llll}\text { Username } & \text { Connotation } & \text { Username } & \text { Connotation } \\ \text { zex } & \text { sex } & \text { azz } & \text { ass } \\ \text { 6ybeast } & \text { sexy beast } & \text { sixo } & \text { sexo/nymphomaniac } \\ \text { 6ykitten } & \text { sexy kitten } & \text { cex } & \text { sex }\end{array}$

Phonemic replacement is a process in which Gamedesire users replace a phoneme in a word with another phoneme that is alliteratively, consonantally, or assonantally similar, but not identical, to it. There is what Short (1996) terms "loose alliteration" between "zex" and "sex" which are phonetically distinguished by the z-s contrast: alveolar, fricative, and voiced in contradistinction to alveolar, fricative, and voiceless, respectively. Sharing all distinctive articulatory features except one makes them loosely alliterative. Similarly speaking, there is loose consonance between "azz" and "ass" and loose assonance between "i" in "6y" and "e" in "sexy": short, high and front against short, mid and front, respectively. These usernames, however, are instances of phonemic and orthographic deviations. No smart, knowledgeable, and experienced speaker of English has difficulty putting all intended mispronunciations and misspellings in their correct forms.

\subsubsection{Deletion}

$\begin{array}{llll}\text { Username } & \text { Connotation } & \text { Username } & \text { Connotation } \\ \text { XTC [ecstasy] } & \text { sexual passion } & \text { make [love] } & \text { sexual intercourse } \\ \text { mng [moan and groan] } & \text { sexual arousal } & \text { have [sex] } & \text { sexual intercourse } \\ \text { letsdo [it] } & \text { sex } & & \end{array}$

Deletion is used here as a general term applicable to sounds as well as to words. The deletion of sounds is referred to as elision (sounds are elided); deletion of words as ellipsis (words are ellipted). The nicks "XTC" and "mng" are examples of elision; the rest of ellipsis. The weak vowel " $\partial$ " in "ecstasy" is typical of syncopic elision; "n" in "mng" of aphetic and apocopic elisions. Crystal $(2003 ; 2008)$ includes ellipsis in the domain of grammar and elision in that of phonetics and phonology. Though intended as evasive or ambiguous, usernames cause great proliferation of euphemisms marked by deletions to palliate what could not be named directly.

\subsubsection{Borrowing}

$\begin{array}{ll}\text { Username } & \begin{array}{l}\text { Connotation } \\ \text { horny }\end{array} \\ \text { sayha (Arabic) } & \text { menstruation } \\ \text { doody (Arabic) } & \text { illicit fucker } \\ \text { paramour (French) } & \text { gay/homosexual } \\ \text { Gai (French) } & \text { threesomes } \\ \text { trois (French) } & \text { sex } \\ \text { Geschlecht (German) } & \text { penis }\end{array}$

Username
Dirne (German)
puta (Spanish)
lesbica (Italian)
schmock (Yiddish)
fornix (Latin)
fellatiO (Latin)

Connotation
whore
whore
lesbian/homosexual
penis
fornication
oral sex

Enright (1985) mentions that an element of euphemization resides in the borrowing of foreign words and phrases whereby what is referred to is so rare among us that we have to import from other languages to describe it. The element is borrowing (see Crystal, 2003, 2008). Loanwords are borrowings imported from one language to be used in another by people who do not speak the 'exporting' language. The loaned usernames sayha and doody are also instances of transliteration, whereby the alphabetical letters of Arabic are rendered into those of English. Gamedesire users employ this method in creating a username into one language using the alphabet of another.

\subsubsection{Semantic Innovation}

\subsubsection{Particularization}

Username
SaTisFacTioN
untouchable
clean
getitup
lover
mistress
enjoyable

Connotation
orgasm
unfuckable
sexual disease-free
penis/clitoris erection
sex partner
clandestine sex partner
sexually pleasing

$\begin{array}{ll}\text { Username } & \text { Connotation } \\ \text { Cute } & \text { sexy } \\ \text { pretty } & \text { sexy } \\ \text { wetnwild } & \text { horny } \\ \text { gorgeous } & \text { sexy } \\ \text { Luscious } & \text { sexy } \\ \text { delicious } & \text { sexually enjoyable }\end{array}$

ass 
This mechanism involves the use of a general username in a context where a patent euphemistic meaning is sent by the addresser, but a latent sexual interpretation is received by the addressee. This act of reception requires the general username to be "particularized" and assigned a specific sexual sense. "Satisfaction", e.g., is a generalized term for the gratification acquired when a need is fulfilled, but is particularized for the orgasm attained at the end of sexual intercourse. The username "getitup" includes the pronoun "it" which refers generally to anything that is gotten up, but particularly to penile or clitoral erection.

\subsubsection{Implication}

\begin{tabular}{llll}
$\begin{array}{l}\text { Username } \\
\text { sleeper }\end{array}$ & Connotation & Username & Connotation \\
touchme & fucker & willing & sexually inclined \\
pleasurable & fuck me & BackDoor & ass \\
Passionate & sexually enjoyable & loose & sexually available \\
intimate & sexually impassioned & thrill & sexual orgasm \\
GetLaid & intrinsically sexual & frontdoor & pussy \\
\hline
\end{tabular}

This semantic mechanism comprises usernames whose sexual connotations are not directly communicated but are implied by the addresser and inferred by the addressee. Technically speaking, those usernames in the first and third columns are implicitly communicated and thus are termed "implicatures" (Crystal, 2008), whereas those in the second and fourth columns are explicitly conveyed and thus are termed "explicatures" (Crystal, 2008). Warren (1992) explains "implication" as the invariable concomitance between the contextual and conventional referents, which generates an antecedent-consequent relationship between them, i.e., if X then Y. To "have sex" implies sleeping, getting laid and willingly and loosely touching somebody in a passionate and intimate way to have a pleasurable thrill from front or from behind.

\subsubsection{Metaphor}

$\begin{array}{llll}\text { Username } & \text { Connotation } & \text { Username } & \text { Connotation } \\ \text { Preyer } & \text { sexually predatory } & \text { globes } & \text { breasts } \\ \text { Gates } & \text { pussy, asshole, mouth } & \text { screwed } & \text { fucked } \\ \text { balls } & \text { testicles, breasts } & \text { RIDER } & \text { mounting in copulation } \\ \text { threedoors } & \text { pussy, asshole, mouth } & \text { Wolfess } & \text { sexually aggressive female }\end{array}$

Metaphor draws comparison between two referents: the "conventional" and the "contextual" in Warren's terms (1992), "tenor" and "vehicle" in Leech's terms (1969). Both referents have some likeness in common (ground of comparison) or, as Warren (1992) puts it, "some property of the conventional referent is also a property of the contextual referent". That is the case when vaginas are likened to doors and gates (both can be opened and penetrated); testicles and breasts to balls and globes (both have circular or oval shapes); and a sex partner to a wild animal (both eat up ravenously). The usernames above are metaphorized in such a way to express the user's euphemistic attitude towards the referent and bring to our knowledge some newly discovered similitude.

\subsubsection{Metonymy}

\begin{tabular}{llll}
$\begin{array}{l}\text { Username } \\
\text { he/she }\end{array}$ & Connotation & Username & Connotation \\
himher & bisexual & rear & ass \\
he & effeminate & DoIt & sex \\
She & penis & sitonit & penis \\
cumcum & pussy & TakeIt & penis \\
\hline & orgasm & mything & penis/vagina
\end{tabular}

Metonymy establishes some association between two referents termed by Warren (1992) co-occurrence relation between the conventional and contextual referents. Like metaphorical euphemisms, metonymic ones transfer us from the dysphemistic domain to the euphemistic through an affinity relation between the substituted and the substituted-for in the former trope or through a contiguous relation in the latter. The metonymic euphemisms above relate the conventional and contextual senses in the following ways: (a) general-for-specific: he and/or she for a bisexual partner sexually oriented towards both sexes, (b) whole-for-part: he (an entire male organism) for penis (a male organ), (c) cause-for-effect: cumcum (i.e., come) for orgasm; (d) location-for-located: rear for ass, and (e) unnamed-for-named: it for sex and thing for penis or pussy.

\subsubsection{Reversal}

$\begin{array}{llll}\text { Username } & \text { Connotation } & \text { Username } & \text { Connotation } \\ \text { ugly } & \text { sexually unattractive } & \text { chilly } & \text { sexually cool } \\ \text { SoCold } & \text { sexually cold } & \text { icicle } & \text { sexually cold } \\ \text { freezy } & \text { sexually cold } & \text { badlooking } & \text { sexually unattractive }\end{array}$


Warren's "reversal" (1992) is reminiscent of Ford's (1968) and Leech's (1969) “irony", a device of euphemism whereby an offensive word is expressed with a mild one. It is a way of saying something literally and meaning its opposite figuratively. However incapable of entering the cranium of the coiners to read their intentions, we do not normally tend to believe the conventional sense, because bearers of usernames intend the opposite of what they write and none of them tends to underestimate his or her physical constitution: ugly and bad-looking for gorgeous; cold, freezy, chilly, and icicle for hot.

7.1.4.6 Understatement or Litotes

$\begin{array}{llll}\text { Username } & \text { Connotation } & \text { Username } & \text { Connotation } \\ \text { indifferent } & \text { cold } & \text { Unwilling } & \text { disinterested } \\ \text { notbad } & \text { good } & \text { unwanted } & \text { discarded } \\ \text { NotGood } & \text { bad } & & \end{array}$

Litotes is an understatement in which an affirmative meaning is expressed by negating its opposite. The negative meaning is brought home to us either through the negative particle not or through a negative prefix such as inand un-. In litotic euphemisms, Gamedesire users tend to downgrade (Warren's term) a particular sexual sense. Though not a meaning-changing tool, understatement or litotes can be combined with a meaning-changing one, i.e., irony since the user writes something but means its opposite. Therefore, it is admitted that litotic instances can be classed as ironical. The interpreter may not accept it, though. Understatements suit the aim of euphemism since something "bad" is expressed by something "less bad". Leech (1969) regards litotes as distorting the truth by saying too little.

\subsubsection{Overstatement or Hyperbole}

$\begin{array}{llll}\begin{array}{l}\text { Username } \\ \text { eatenup }\end{array} & \text { Connotation } & \text { Username } & \text { Connotation } \\ \text { edible } & \text { consumed } & \text { TooHungry } & \text { starving } \\ \text { steamy } & \text { eatable } & \text { impassioned } & \text { excited } \\ \text { Dirty } & \text { hot } & \text { Burning } & \text { excited } \\ \text { kinky } & \text { nasty } & \text { lewd } & \text { lascivious } \\ \text { TWISTY } & \text { deviant } & \text { flaming } & \text { burning } \\ \text { OILED } & \text { abnormal } & \text { FlamingLips } & \text { burning } \\ \text { horny } & \text { Delirious } & \text { frenzied }\end{array}$

Contrary to litotes, hyperbole is an overstatement in which truth, as Leech (1969) puts it, is distorted by saying too much. In hyperbolic euphemisms, Gamedesire users tend to upgrade (Warren's term) their sexual excitement by extravagant exaggerations. Whereas litotic euphemisms are ironical, hyperbolic euphemisms are metaphorical. Most of the litotic and hyperbolic phrases are equivocal, since they can be assigned more than one interpretation. The motivation behind overstatements is to overestimate one's sexual status to grab birds of the same feather, i.e., players with the same interests.

\subsubsection{Proper Naming}

$\begin{array}{llll}\text { Username } & \text { Connotation } & \text { Username } & \text { Connotation } \\ \text { cAsAnOvA } & \text { fucker } & \text { CaptainHook } & \text { penis } \\ \text { donjuan } & \text { fucker } & \text { redsea } & \text { pussy } \\ \text { juliuscaesar } & \text { penis } & & \end{array}$

This is an onomastic mechanism that employs historical names designating sexual referents or develops new ones. Some of the Gamedesire users act as nomenclators assigning existing or new names to sexual designata. Casanova and Don Juan are notorious for their affairs with women and therefore are envisaged as womanizers or dysphemistically as fuckers. Julius Caesar and Red Sea whose conventional referents are respectively the Roman dictator and a body of water are contextually assigned new referents: penis and pussy, respectively. Perhaps the common link between Julius Caesar and the penis is showing powerful masculinity in action. The conventional fixed phrase Red Sea (water body) carries the stress pattern primary-tertiary, in which the lexeme Red assigns no colour to the Sea, whereas the contextual phrase redsea carries the stress pattern secondary-primary, in which the adjectival modifier red is used in an extended sense to describe the vaginal color from inside. The common link between the Red Sea and the vagina is that both share the color and are swimmable. CaptainHook is an invented name given to the male genital, i.e., the penis, due to formal resemblance.

7.2 Euphemistic Categories not Developed by Warren (1992) and Ham (2001, 2005)

\subsubsection{Neologism}

$\begin{array}{llll}\text { Username } & \text { Connotation } & \text { Username } & \text { Connotation } \\ \text { monthy } & \text { menstruation } & 69 \mathrm{er} & \text { have mutual oral genital sex }\end{array}$

Neologism, also known as coinage, is regarded by Leech (1969) as lexical deviation, one of the most transparent 
devices in which Gamedesire users exceed the normal boundaries of language and invent new words which become in common usage despite the fact that these words have no entries in language dictionaries. These words are called 'nonce-formations' by Leech (1969) and 'nonce-words' by Hurford and Heasley (1983), being coined on spur of the moment. On a particular occasion or in a given context, Gamedesire users need to convey a sexual meaning but find no lexical entry in language dictionaries for that meaning. Hence, they tend to exploit a word-formation process such as affixation to establish the needed meaning.

\subsubsection{Conversion}

$\begin{array}{llll}\begin{array}{l}\text { Username } \\ \text { sexme }\end{array} & \begin{array}{l}\text { Connotation } \\ \text { have sex with me }\end{array} & \begin{array}{l}\text { Username } \\ \text { beerme }\end{array} & \begin{array}{l}\text { Connotation } \\ \text { get dunk and laid }\end{array}\end{array}$

This is a zero-derivational word-formation tool whereby Gamdesire users shift a lexical unit from its normal word class to a new contextual one without adding affixes (see Crystal, 2008). Although there is no orthographic shift in sex (noun/verb) and beer (noun/verb), there is a shift in meaning. Sex and beer which are lexically entered as nouns are pragmatized on the website under study as verbs connoting sexual desire. A fully detailed discussion of these two instances comes in Section 8.

7.2.3 Iconicity

$\begin{array}{llll}\text { Username } & \text { Connotation } & \text { Username } & \begin{array}{l}\text { Connotation } \\ (!+)\end{array} \\ \left(\begin{array}{l}\text { regular ass } \\ (!)\end{array}\right. & \text { big ass } & (.)(.) & \text { tiny breasts } \\ (\mathrm{y}) & \text { pussy } & (\mathrm{o})(\mathrm{o}) & \text { normal breasts } \\ 9966 & \text { anal sex } & 39\{.\} & \text { shrivelled breasts } \\ 63 & \text { oral-genital sex } & & \text { anal licking }\end{array}$

This is a semiotic-signifying process in which Gamedesire users utilize iconic signs in place of offensive words to describe a dynamic object euphemistically. The use of nonverbal representations is caused by the ineffability cast upon the verbal alternatives. The users are prohibited by Gamedesire etiquette from expressing these in words. Therefore, they resort to icons to communicate the incommunicable. The ideographs in the left columns are iconic because their shapes picture their meanings. The numerals 3,6 and 9 which arbitrarily give no clue to their meanings are used in a creatively iconical way to convey an analogy between their shapes and the shape of the human body: circle for head, tail for leg and brackets for buttocks. A worldwide iconic example is 69 for reciprocal oral sex between engaged partners (Note 4).

7.2.4 Cloning, also Known as Reduplication

\begin{tabular}{|c|c|c|c|}
\hline Username & Connotation & Username & Connotation \\
\hline peepee & urinate/ejaculate/masturbate & awawaw & excitement/orgasm \\
\hline googoo & semen & ohohoh & excitement/orgasm \\
\hline weewee & penis & awawawaw & excitement/orgasm \\
\hline woowoo & pussy & ohohohoh & excitement/orgasm \\
\hline DillyWilly & penis & & \\
\hline
\end{tabular}

'reduplication' is a word-formation process whereby the whole or part of the base is copied many times and attached to the base (see Katamba, 1993; Haspelmath, 2002). Bauer (2003) assigns reduplication two meanings: a) the formation of new affixes by repeating some part of the base (possibly the whole base) and b) the formation of new words using affixes created in this manner. The part which has been repeated to make the reduplicated word is called 'reduplicant'. As shown above, there can be reduplication of a full word (tautonym, as in peepee) or of part of the word with alternation or omission of an initial or medial sound (as in DillyWilly). For terminological simplicity, the biological term cloning has been imported in substitution for the complicated process of adding prefixes such as re-, tri-, quadru-, quinqu-, and so forth, to plication to show how many times a part or a whole has been copied.

\subsubsection{Back-Formation}

$\begin{array}{llll}\text { Username } & \text { Connotation } & \text { Username } & \text { Connotation } \\ \text { nake } & \text { naked (sex) } & \text { liaise } & \text { liaison (sex) } \\ \text { Lech } & \text { lechery (sex) } & & \end{array}$

Back-formation is 'an abnormal type of word-formation where a shorter word is derived by deleting an imagined affix from a longer form already present in the language' (Crystal, 2008). Gamedesire users create usernames in this limited way by back-forming verbs from nouns removing an actual or supposed affix from existing words, as in nake from naked, lech from lechery and liaise from liaison. Of these only nake has no dictionary meaning. 


\section{Results and Discussion}

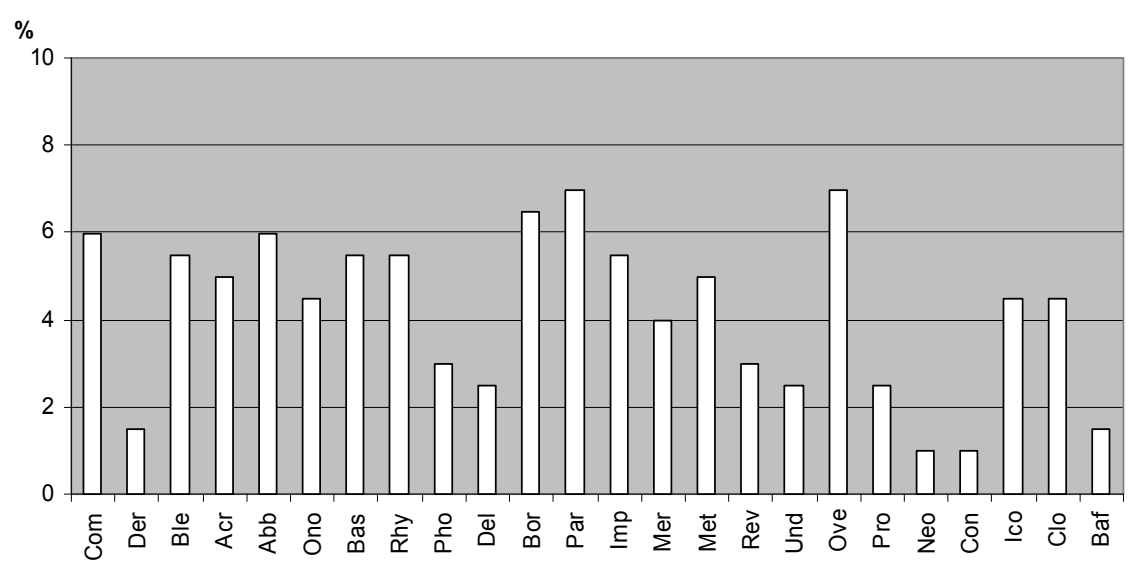

Figure 3. Statistical distribution of categories of euphemism across the dataset

Figure 3 provides a statistical breakdown of the collected sample of usernames across all categories. The chart shows Overstatement (Ove), Particularization (Par), and Borrowing (Bor) as the largest categories, taking up over $60 \%$ and thus dominating over the others. Next to these three come Compounding (Com), Blending (Ble), Acronymy (Acr), Abbreviation (Abb), Onomatopoeia (Ono), Back-slang (Bas), Rhyme-slang (Rhy), Implication (Imp), Metonymy (Met), Iconicity (Ico), and Cloning (Clo), ranging between $40 \%$ and $60 \%$. Between $20 \%$ and 40\% come Phonemic Replacement (Pho), Deletion (Del), Reversal (Rev), Metaphor (Mer), Understatement (Und), and Proper Naming (Pro). Derivation (Der), Neologism (Neo), Conversion (Con), and Back-formation (Baf) are assigned less than $20 \%$. The variance between the highest and the lowest categories shows a priority given by GD users to some categories over the others. Based on the previous sample analysis, a number of findings can be enumerated. The analysis shows that the users of http://www.gamedesire.com make frequent use of many euphemisms. In doing so, they enrich the 'chatty' language, save the face from social and moral threats, ensure continuity on the website, and guard against any possible bans from the website administrators. This is achieved through the use of a wide range of linguistic and rhetorical devices, most of which are highlighted in Warren's (1992) model, but some of which had to be furnished in a newer rendition of the model proposed at the end of this article (see Appendix 1). Modification was a necessity to include many examples not fitting into the categories provided by Warren (1992) and $\operatorname{Ham}(2001,2005)$. These new categories are considered an addition, not a deficiency as Ham (2001) claims. They are not inferior to, but are as important as, the old categories. On this view Halliday (1978) comments that there is no reason to say one way is better than another; but it is important to find out how the speakers of a particular language in fact set about creating new terms when faced with the necessity of doing so. However, as long as language is constantly changing and new coinages trickle into its dictionaries every day or are just pragmatized, the model is open for further development and what has been done is just a seminal work. It is also found that some of the model constituent items tend to overlap and readers can find a username simultaneously applicable to or subsumable under two or more categories. Take the cases of the usernames mng and XTC which can be listed under elision and abbreviation; sayha and doody under borrowing (derived/loanwords) and transliteration; wetnwild under deletion (elision), implication, and overstatement; frontdoor under compounding, implication, and metaphor; freezy and icicle under metaphor, irony, overstatement, and coinage; redsea under compounding, metaphor, and overstatement; and $69 \mathrm{er}$ under derivation and coinage. It is now obvious that certain euphemism-formation methods are not clear cut, being overlapped in the data analyzed, where different kinds of strategies can be used for face-saving purposes.

The analysis demonstrates that Gamedesire usernames tend to be euphemistic (face-saving) and dysphemistic (face-threatening) in different ways. The choice between the euphemistic and the dysphemistic seems entirely dependent upon an individual basis, not on the context. However futile it is to tear a word out of its context, contextualization is limited in the study. The ignoring of contexts in any act of interpretation is a weak practice, rather a vicious one (Hayakawa, 1965). Hayakawa's view is right, but some words, strictly usernames, cannot be contextualized with empty profiles of GD users and therefore are apt to multiple interpretations. Word meanings are not consistent and static (Ham, 2005) but dynamic and negotiable (Warren 1992). The multiplicity of interpreting a username is the aura of what the addressee perceives. It is also notable that some of the analyzed usernames are marked by word play such as insertion of rebus-like words (as in $3 c s$ for threesies), writing a 
whole nickname or part thereof in lower-case, upper-case letters (as in lewd and OILED), or a mixture of both (as in SaTisFacTioN). Some GD nicknames in the sample of analysis illustrate that their bearers have a strong tendency to cut part of the nickname either initially, medially (as in uns for undies) or finally (as in nympho for nymphomaniac). Leech (1969) terms these initial, medial, and final omissions aphesis (aphaeresis or prosiopesis in Crystal, 2008), syncope, and apocope, respectively. Another catchy finding is the tendency to re-semanticize (Halliday's reinterpret) existing words. By 're-semanticizing', it is meant that GD users tend to construct and assign totally new meanings to certain lexical items with fixed sense entries in English dictionaries, as in sexme and beerme whereby the familiar lexical meaning of sex as a verb is to 'label as male or female' and that of beer as a noun is 'alcoholic liquor'. This process is dubbed 'conversion' (see Katamba, 1993; Bauer, 2003; Štekauer \& Lieber, 2005), a word-formation (zero-derivational) strategy in which there is a change in the part of speech of a word without affixation marking the change. It is by act of colloquialism or slang that sex as a verb means 'to have sexual intercourse' and beer as a verb means 'to make drunk'; even both should be followed by the particle 'up'. Of these two, the verb sex has virtually passed a semantic extension whereby it takes on a further and newer meaning than the meaning it originally has in language dictionaries. Lexically, the word sex as a noun is polysemic, being used for 'intercourse' and 'gender', but as verb is monosemic, with one meaning 'to identify as male or female'. By analogy and conversion, the monosemic verb sex is semantically expanded, putting on the meaning of 'intercourse' taken on by its noun, i.e., 'to have sex'. Within GD speech community, this new meaning of the verb is now much more current than its old meaning. Examples as such show a clear distinction between the lexical meaning and the contextual meaning, which have not necessarily to coincide together. By the same token, lexical meaning and contextual meaning entail an ensuing distinction between a referent designated by dictionaries and a referent designated by particular contexts, as in wolfess designating an animal and a human. There is a particular clue of connection between both referents: a rapacious female sex partner is metaphorically likened in her sexual act to a ravenous female wolf in its brutal attack on a prey.

\section{Conclusion}

That the explosion of the Internet is fundamentally transforming the world in which we live, work, govern, and communicate is a fact that has attracted much academic attention in the last decade. This is evidently clear from the proliferating chain of publications entitled "The impact of the Internet on ..." (Crystal, 2001)

A great number of GD usernames carry cryptic sexual connotations - by connotation one means the suggestion of an additional meaning apart from the dictionary meaning a username denotes. Language users use different styles of log-in on www.gamedesire.com marked by grammatical (change of word grammar), lexical (creation of new words), phonological (irregularity of pronunciation), graphological (irregularity of spelling), and semantic deviations (transference of meaning). However, the original model and its new renditions are not, never have been, and seem unlikely ever to be, meant to enumerate all the mechanisms by which GD users break language rules and deviate from its norms. Since there are personal, social, moral, and technical constraints on the dos (what to say/do) and don'ts (what not to say/do), i.e., universal unspeakables, these devices are used to sidestep administrators' warnings and bans, to bypass explicitness and offensiveness, and to conceal intentionality and directness. More attention is needed to discover what linguistically happens when a username is formed. The more usernames are created, the more euphemisms and linguistic devices are employed.

Additionally, the fact that all world languages use euphemism is universally accepted. Halliday (1978) holds that all languages have more than one mode of word-creation; different modes are adopted for different purposes. In Vernacular Arabic (VA), par exemple, many of the proposed categories, not all, are applicable, such as the hyperbole yiftah akkah (invading Acre) for (breaking the hymen in virginal sex) and the metaphor yifaddy guzah (emptying the hookah) for 'urination, masturbation, or ejaculation'. Likewise, Qur'anic Arabic (QA) spawns a variety of euphemistic substitutes for sex and sexual relations, and that is why the word sex (Arabic jins) has no mention throughout this Book. Instead innocuous words are employed to maintain physical balance and avoid sexual arousal. Typical examples include the metaphor clothing (Arabic libasun), the metonym touch (Arabic lamastum), the innuendo plough (Arabic harthun) and the litotes not a good deed (Arabic amalun ghayru salih), to name but a few. Other euphemisms, which can technically be termed antonomasias, for getting round naming God include the ninety-nine attributive sobriquets (Fairest Names), such as the Almighty (al-qadir), the Eternal (al-samad), the Creator (al-khaliq), the Resurrectionist (al-bacith), the First (al-awwal), and the Last (al-akhir), in addition to the omni-qualities such as the Omnipresent, the Omnipotent, and the Omniscient. The reverence for naming God spreads to his prophet Muhammad, for whom there are many euphemistic sobriquets as the Prophet (al-nabiyy), the Messenger (al-rasul), the Seal (al-khatam), the Herald (al-bashir/al-nadhir), the Example (al-uswah), and so forth. VA and QA euphemisms cross-linguistically prove that, as Howard (1983) 
explains it, euphemism varies from age to age and culture to culture and the methods are manifold: abbreviate, borrow a foreign tongue, use litotes, use a vague phrase, use circumlocution, be enigmatical or poetical, use concomitant circumstance, be bombastic, use understatement, hint, direct thought, and reversible phrases. Howard (1983) and Lawler (cited in Hines, 1999) inspire the best conclusion here:

Euphemism is one of the agents of change in a language. It always has and it always will. (Howard, 1983)

And if there is this much here, what might there be elsewhere? (Lawler, 1990 quoted in Hines, 1999)

\section{Acknowledgments}

I sincerely thank the MHESR ParOwn Initiative for funding a scholarship to the University of Portsmouth in the UK where this paper has been initiated under the auspices of Chris Sinha, Professor of Psychology of Language and First President of the UK Cognitive Linguistics Association. Sinha reviewed major parts of it and showed much enthusiasm and stalwart support for the topic.

\section{References}

Adams, M. (1999). Another effing euphemism. American Speech, 74(1), 110-112. https://doi.org/10.1215/00031283-79-1-110

Al-Khamash, S. S. (1991). Addad: A Study of Homo-polysemous Opposites in Arabic. Doctor's dissertation, Indiana University, Indiana, US.

Allan, K., \& Burridge, K. (2006). Forbidden words: taboo and the censoring language. Cambridge: Cambridge University Press. https://doi.org/10.1017/CBO9780511617881

Baldick, C. (2004). The concise Oxford dictionary of literary Terms. Oxford: Oxford University Press.

Bauer, L. (2003). Introducing linguistic morphology (2nd ed.). Edinburgh: Edinburgh University Press.

Booij, G. (2005). The grammar of words. Oxford: Oxford University Press.

Burchfield, R. (1985). An outline history of euphemisms in English. In D. J. Enright (Ed.), Fair of speech: the uses of euphemism (pp. 13-31). Oxford: Oxford University Press.

Calvo, J. J. (2005). Sexual euphemisms in the history of the English language: sample probe. In S. José (Ed.), The language of sex: saying and not saying (pp. 63-74). Valencia: Universidad de Valencia.

Clerk, V. A. d., \& Bosch, B. (1997). The sound patterns of English nicknames. Language Sciences, 19(4), 289301. https://doi.org/10.1016/S0388-0001(96)00070-8

Cooper, B. (2008). Contribution to the study of euphemism in the intimate lexis of Slavonic and Germanic languages. Transactions of the Philological Society, 106(1), 71-91. https://doi.org/10.1111/j.1467-968X.2007.00196.x

Crespo-Fernández, E. (2006). The language of death: euphemism and conceptual metaphorization in Victorian obituaries. SKY Journal of Linguistics, 19, 101-130.

Crespo-Fernández, E. (2015). Sex in language: euphemistic and dysphemistic metaphors in internet forums. London: Bloomsbury.

Crystal, D. (2001). Language and the internet. Cambridge: Cambridge University Press. https://doi.org/10.1017/CBO9781139164771

Crystal, D. (2003). A dictionary of linguistics and phonetics (3rd ed.). London: Blackwell Publishing.

Crystal, D. (2008). A dictionary of linguistics and phonetics $(6$ th ed.). Oxford: Blackwell. https://doi.org/10.1002/9781444302776

Culpeper, J. (1996). Towards an anatomy of impoliteness. Journal of Pragmatics, 25, 349-367. https://doi.org/10.1016/0378-2166(95)00014-3

Cunningham, E. V. (1956). Euphemism in a children's counting-out rhyme. Western Folklore, 15(3), 197-198. https://doi.org/10.2307/1497315

de Kadt, E. (1998). The concept of face and its applicability to the Zulu language. Journal of Pragmatics, 29, 173-191. https://doi.org/10.1016/S0378-2166(97)00021-0

Diebold, A. R. (1961). American-Spanish euphemisms by Charles E. Kany. Book Review, 37(2), 289-292. https://doi.org/10.2307/410863

Duckworth, T. (2008). A dictionary of slang: English slang and colloquialisms used in the United Kingdom. 
Retrieved from http://www.peevish.co.uk/slang/index.htm

Enright, D. J. (1985). Fair of speech: the uses of euphemism. Oxford: Oxford University Press.

Epstein, J. (1985). Sex and euphemism. In D. J. Enright (Ed.), Fair of speech: the uses of euphemism (pp. 56-71). Oxford: Oxford University Press.

Escandell-vidal, V. (1996). Towards a cognitive approach to politeness. Language Sciences, 18(3-4), 629-650. https://doi.org/10.1016/S0388-0001(96)00039-3

Fan, Z. (2006). The mechanism of euphemism: a cognitive linguistic interpretation. US-China Foreign Language, $4(7), 71-74$.

Farlex. (2008). Dictionary of sexual terms: the language of love, lust and sex. Farlex, Inc. Retrieved from http://www.sex-lexis.com

Ford, J. M. (1968). The son of man: a euphemism. Journal of Biblical Literature, 87(3), 257-266. https://doi.org/10.2307/3263537

Friend, H. (1881). Euphemism and tabu in China. The Folk-Lore Record, 4, 71-91. https://doi.org/10.1080/17441994.1881.10602605

Gladkova, A. (2013). The semantics of nicknames of the American presidents. In C. Peter \& A. Mengistu (Eds.), Proceedings of the 2002 Conference of the Australian Linguistic Society. Retrieved from http://www.als.asn.au

Graham, G. (1999). The internet: a philosophical enquiry. London and New York: Routledge.

Halliday, M. A. K. (1978). Language as social semiotic: the social interpretation of language and meaning. London: Edward Arnold Ltd.

Ham, K. (2001). The linguistics of euphemism: a diachronic study of euphemism use and formation. Master's thesis, University of Surrey, Surrey, UK.

Ham, K. (2005). The linguistics of euphemism: a diachronic study of euphemism use and formation. Journal of Language and Linguistics, 4(2), 227-263.

Haspelmath, M., \& Sims, A. D. (2002). Understanding morphology (2nd ed.). London: Arnold.

Hatim, B. (1997). Communication across cultures: translation theory and contrastive text linguistics. Exeter: University of Exeter Press.

Hayakawa, S. I. (1956). Language in thought and action (2nd ed.). London: George Allan and Unwin Ltd.

Hedges, J. (1976). Whifflecate: a folk euphemism. American Speech, 51(3/4), 282-283. https://doi.org/10.2307/454982

Herring, S. C. (1996). Computer-mediated communication: linguistic, social, and cross-cultural perspectives. Amsterdam and Philadelphia: John Benjamims Publishing Company. https://doi.org/10.1075/pbns.39

Hines, C. (1999). Foxy chicks and playboy bunnies: a case study in metaphorical lexicalization. In K. H. Masako, S. Chris \& W. Sherman (Eds.), Cultural, psychological and typological issues in cognitive linguistics (pp. 9-24). Amsterdam and Philadelphia: John Benjamins Publishing Company. https://doi.org/10.1075/cilt.152.04hin

Holmes, J. (1995). Women, men and politeness. London and New York: Longman Group Limited.

Howard, P. (1984). The state of the language: English observed. London: Penguin Books Ltd.

Hurford, J. R., \& Heasley, B. (1983). Semantics: a coursebook. Cambridge: Cambridge University Press.

Katamba, F. (1993). Morphology. London: The Macmillan Press Ltd. https://doi.org/10.1007/978-1-349-22851-5

Kennedy, R., \& Zamuner, T. (2006). Nicknames and the lexicon of sports. American Speech, 81(4), 387-422. https://doi.org/10.1215/00031283-2006-026

La Cour, A., \& Kromann, J. (2011). Euphemisms and hypocrisy in corporate philanthropy. Business Ethics: A European Review, 20(3), 267-279. https://doi.org/10.1111/j.1467-8608.2011.01627.x

Lapierre, A. (2000). From French to English: some observations on patterns of onomastic changes in North America. Names: A Journal of Onomastics, 48(3-4), 233-242. https://doi.org/10.1179/nam.2000.48.3-4.233

Leech, G. (1969). A linguistic guide to English poetry. London: Longman Group Ltd. 
Leech, G. (1983). Principles of pragmatics. London and New York: Longman Group Ltd.

Liao, C. (2006). Linguistic analysis of nicknames of junior high school students. Journal of Language and Linguistics, 5(1), 68-86.

Marcus, D. (1980). Some antiphrastic euphemisms for a blind person in Akkadian and other Semitic languages. Journal of the American Oriental Society, 100(3), 307-310. https://doi.org/10.2307/601801

Matheson, N. (1999). Talking horrors: James, euphemism, and the Specter of Wilde. American Literature, 71(4), 709-750.

Matthews, P. H. (1991). Morphology (2nd ed.). Cambridge: Cambridge University Press. https://doi.org/10.1017/CBO9781139166485

McArthur, T. (2008). Word-formation from the 1998 concise Oxford companion to the English language. High Beam Research Inc. Retrieved from http://www.encyclopedia.com/doc/1O29-WORDFORMATION.html

McKenzie, M. M. (1992). What I've always known but never been told': euphemisms, school discourse and empowerment. In F. Norman (Ed.), Critical language awareness (pp. 223-237). London and New York: Longman Group UK Ltd.

Meier, A. J. (2005). Passages of politeness. Journal of Pragmatics, 24, 381-392. https://doi.org/10.1016/0378-2166(94)00053-H

Mikics, D. (2007). A new handbook of literary terms. New Haven and London: Yale University Press.

Plag, I. (2003). Word-formation in English. Cambridge: Cambridge University Press. https://doi.org/10.1017/CBO9780511841323

Prince, G. (2003). Dictionary of narratology (revised ed.). Lincoln and London: University of Nebraska Press.

Quirk, R. (1982). Style and communications in the English language. London: Edward Arnold Ltd.

Quirk, R., \& Stein, G. (1990). English in use. London: Longman Group UK Limited.

Rabab'ah, G., \& Al-Qarni, A. M. (2012). Euphemism in Saudi Arabic and British English. Journal of Pragmatics, 44, 730-743. https://doi.org/10.1016/j.pragma.2012.02.008

Robinson, D. (1991). Henry James and euphemism. College English, 53(4), 403-427. https://doi.org/10.2307/378015

Santaemilia, J. (2005). The language of sex: saying and not saying. Valencia: Universidad de Valencia.

Short, M. (1996). Exploring the language of poems, plays and prose. London and New York: Longman.

Spira, I. (2005). Chinese Translations of the Qur'ān: A Close Reading of Selected Passages. Master's thesis, Oslo University, Oslo, Norway. https://doi.org/10.1007/1-4020-3596-9

Štekauer, P., \& Lieber, R. (2005). Handbook of word-formation. Dordrecht: Springer.

Todd, Z., \& Walker, S. (2000). Multilingualism on the net: language attitudes and use of talkers. In P. Lyn \& S. Simon (Eds.), Words on the web: computer-mediated communication (pp. 63-68). Exeter: Intellect Ltd.

van Dijk, J. M. (2006). The network society: social aspects of new media (2nd ed.). London: SAGE Publications Ltd.

Warren, B. (1992). What euphemisms tell us about the interpretation of words. Studia Linguistica, 46(2), 128172. https://doi.org/10.1111/j.1467-9582.1992.tb00833.x

Wherrett, D. (2008). A dictionary of cockney rhyming slang. Retrieved from http://www.watchya.com.

\section{Notes}

Note 1. A person may feel the inner urge to swear, but at the same time may not wish to appear overly coarse in their behavior. To swear at someone or something is to insult and deprecate the object of abuse, as well as to use other kinds of dysphemism. Profane swearing uses dysphemisms taken from the pool of dirty words as well as blasphemous and profane (i.e., irreligious) language (Allan \& Burridge, 2006).

Note 2. Robinson's view is supported by Howard $(1984,101)$ who asserts that most societies are euphemistic about God and religious affairs and that as they become more civilized, they become euphemistic about purgatorial matters of defecation and micturition. 
Note 3. The meanings of these rhyming slang nicknames were counterchecked and counter-referenced according to the Dictionary of Slang by Ted Duckworth (2008).

Note 4. The meanings of iconic signifiers (ideographic iconisms) were quoted from Farlex (2004).

\section{Appendix A}

The modified version of Warren (1992) and Ham $(2001,2005)$.

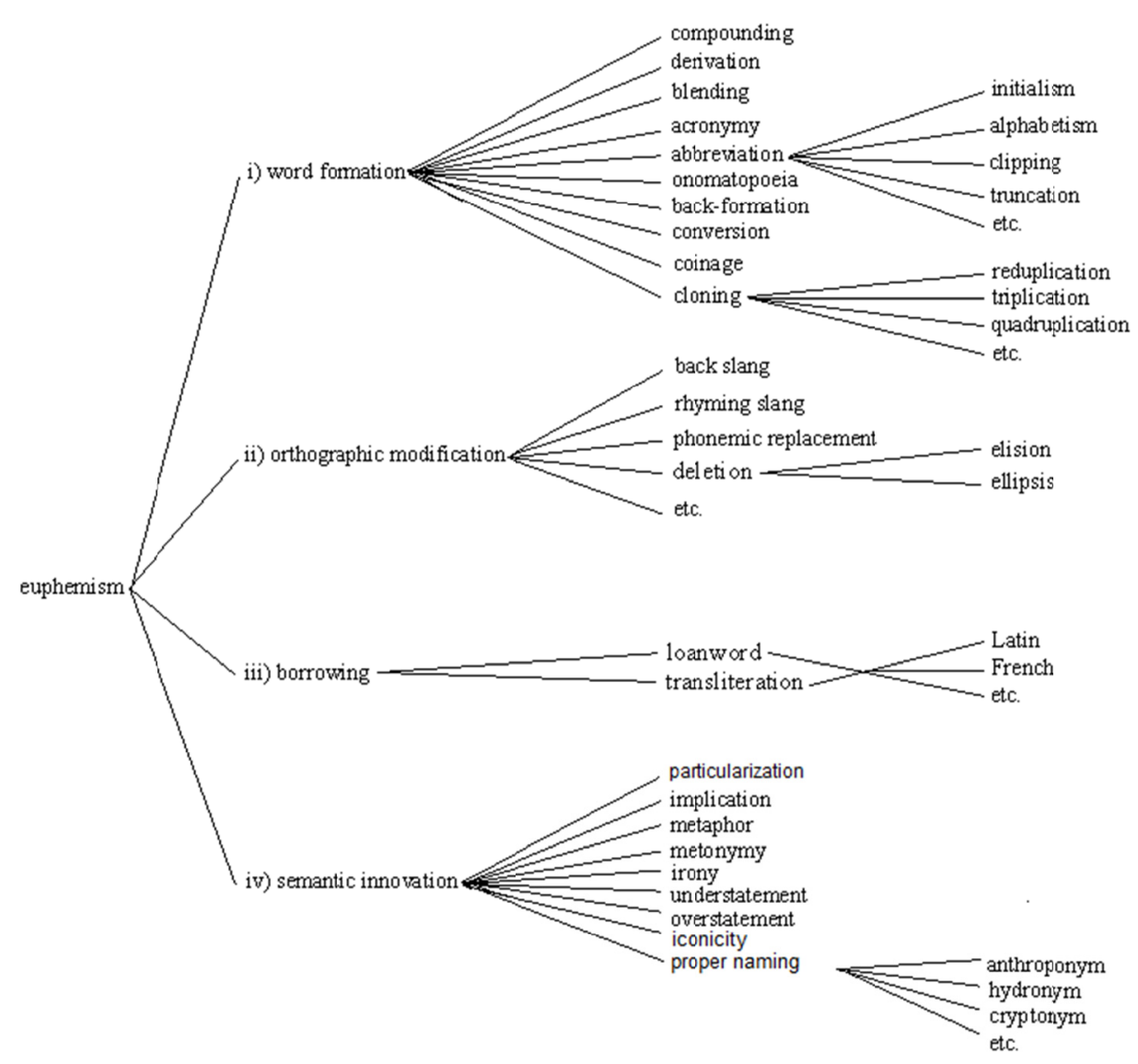

N.B.: The word etc. leaves the model of euphemization open to further linguistic manipulation.

\section{Copyrights}

Copyright for this article is retained by the author, with first publication rights granted to the journal.

This is an open-access article distributed under the terms and conditions of the Creative Commons Attribution license (http://creativecommons.org/licenses/by/4.0/). 